\title{
"Enteric Polymer-Coated Porous Silicon Nanoparticles for Site-Specific Oral Delivery of IgA Antibody"
}

Tushar Kumeria ${ }^{1-2}$, Joanna Wang ${ }^{3}$, Byungji $\mathrm{Kim}^{3}$, Ji-Ho Park ${ }^{4}$, Jon Zuidema ${ }^{1}$, Mark Klempner ${ }^{5}$, Lisa Cavacini ${ }^{5}$, Yang Wang ${ }^{5}$, and Michael J Sailor ${ }^{1}$

${ }^{1}$ Department of Chemistry and Biochemistry, University of California San Diego, USA, CA 92093

${ }^{2}$ School of Materials Science and Engineering, University of New South Wales, Australia, NSW 2052

${ }^{3}$ Materials Science and Engineering Program, University of California San Diego, USA, CA 92093

${ }^{4}$ Department of Bio and Brain Engineering, KAIST, Korea, Daejeon 305-701

${ }^{5}$ University of Massachusetts Medical School, UMASS, Boston, USA, MA- 01655

*E-Mail: $\underline{\text { msailor@ucsd.edu }}$ 

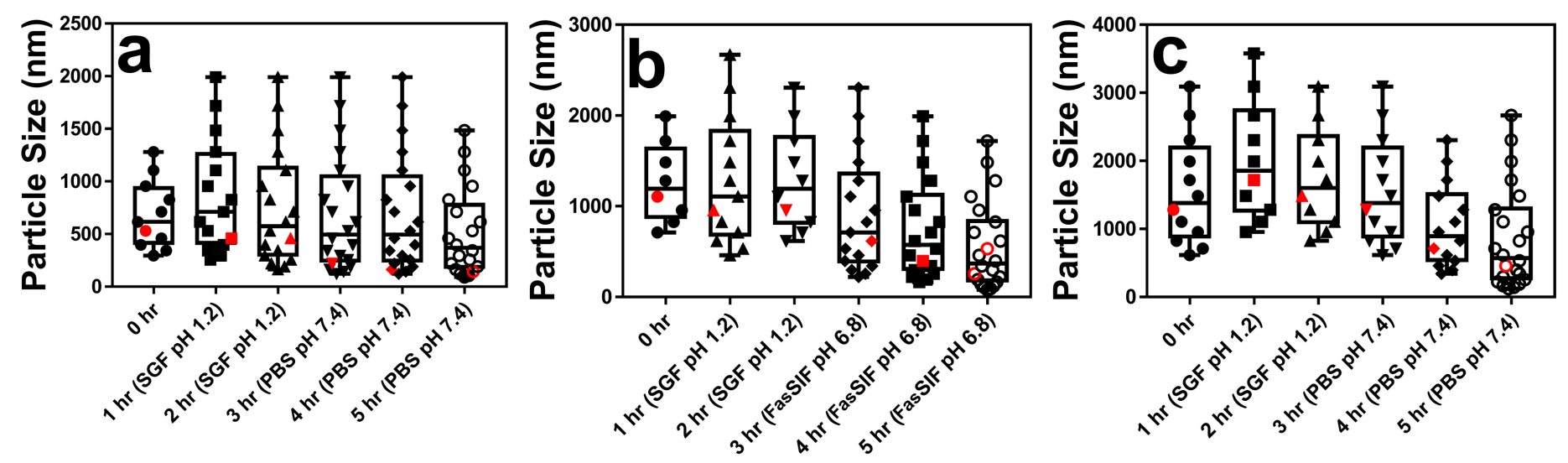

Figure S1. Time-resolved DLS measurement for determining the change in the size of pSi-based oral IgA2 formulations. Box-Whisker plots representing time-resolved measurements of particle size (from DLS peak positions) for different pSibased IgA2 formulations. (a) Uncoated pSi particles at the time points and for the elution media indicated. (b) Eudragit ${ }^{\circledR}$ L100-coated pSi particles. (c) Eudragit ${ }^{\circledR}$ S100-coated pSi particles. The whiskers represent the range of particle sizes present in each experiment, whereas the red data points correspond to the peak value in the DLS data. Two red data points indicate the presence of two peaks in the DLS measurement (i.e., a bi-modal particle size distribution). The "0 hr" time point in the DLS measurements were made using water (at $\mathrm{pH} 3$ ) as a dispersion medium. All pSi particle formulations used here were loaded with IgA2 antibody as described in the text. Temperature throughout all experiments was maintained at $37^{\circ} \mathrm{C}$. 


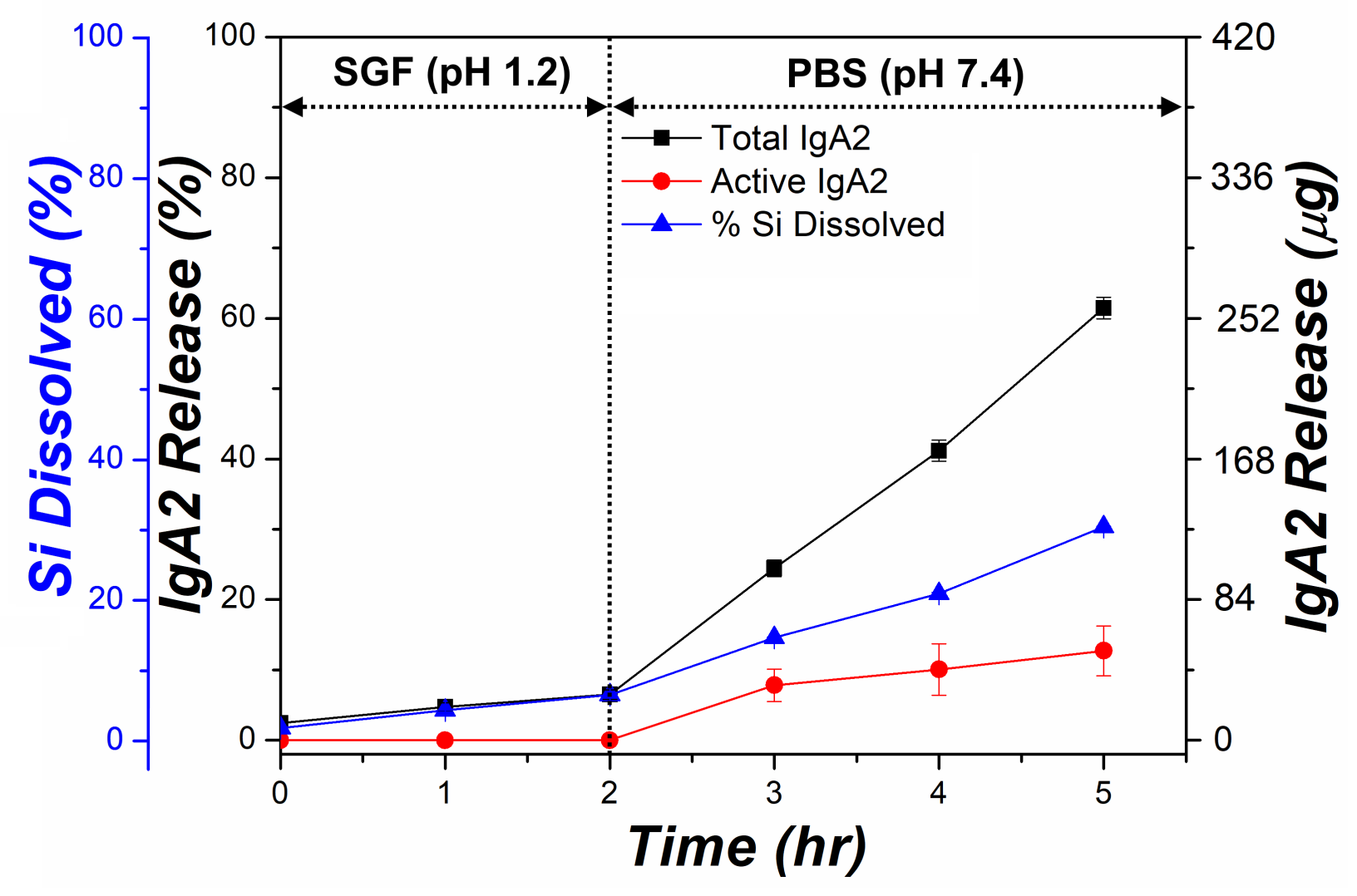

Figure S2. IgA2 release from Eudragit ${ }^{\circledR}$ L100-coated pSi formulation into PBS solution. In vitro temporal release data showing total protein released, total active IgA2 antibody released, and \% Si dissolved from the Eudragit ${ }^{\circledR}$ L100-coated pSi formulation. The first $2 \mathrm{~h}$ of incubation was carried out in simulated gastric fluid (SGF, pH $=1.2$ ) at pH 1.2, and it showed minimal quantities of IgA2 released. At the $2 \mathrm{~h}$ time point, the eluent solution was changed to phosphate buffered saline (PBS, $\mathrm{pH}=7.4$ ), and $60 \%$ of the total IgA2 loaded into the polymer was released into solution in the ensuing $3 \mathrm{~h}$. Of the IgA2 released in this time period, approximately $20 \%$ of its activity was retained. Approximately $30 \%$ of the silicon present in the formulation was released into the eluents during the $5 \mathrm{~h}$ release period. Total protein measured by BCA assay, total active IgA2 antibody measured by ELISA, and \% Si present in solution measured by molybdenum blue assay. 


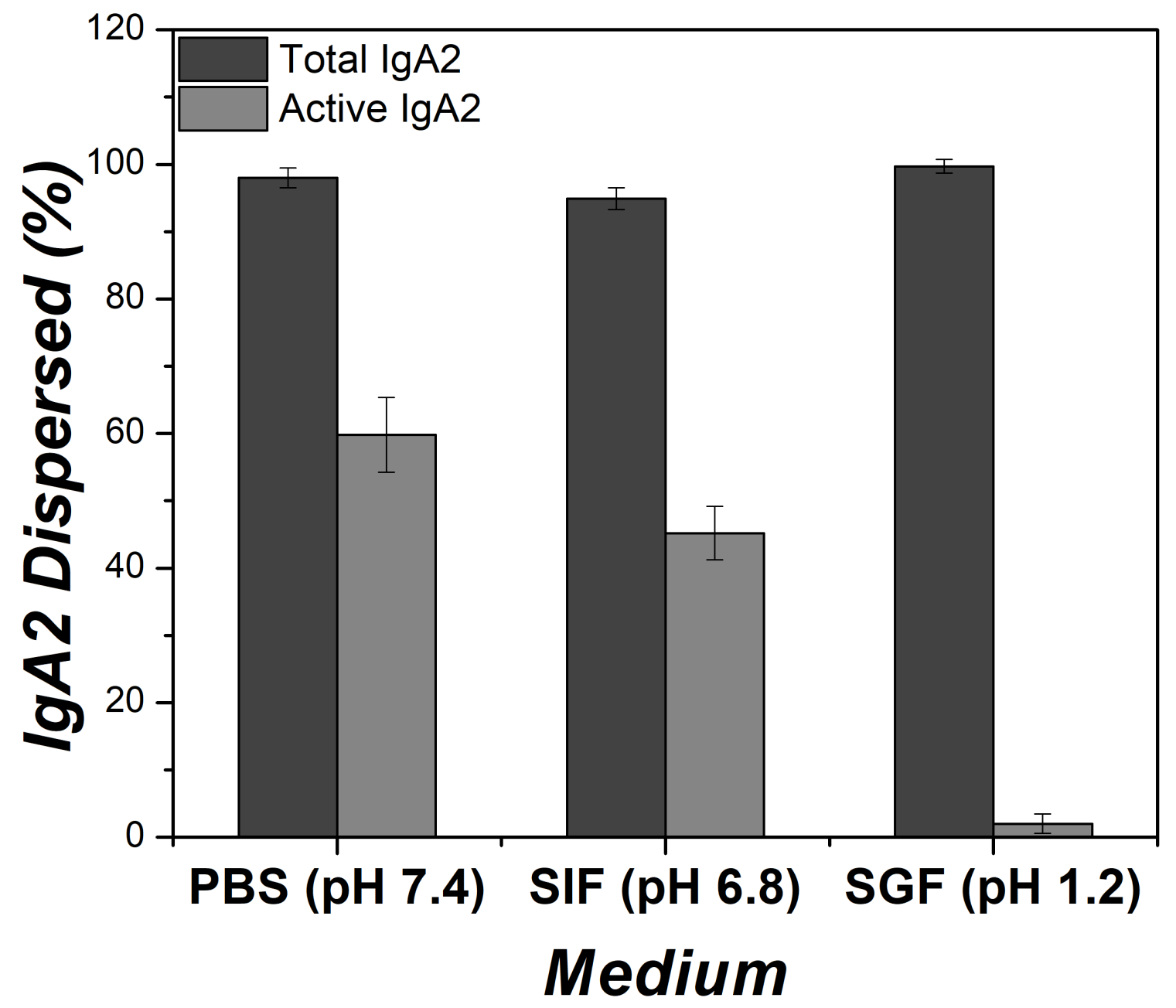

Figure S3. In vitro evaluation of the effect of the vacuum drying procedure on re-dispersibility and activity of IgA2. A solution of IgA2 in each of the indicated buffers (PBS, FasSIF, and SGF) was vacuum dried and then re-dissolved in the same buffer (PBS, FasSIF, or SGF) and the total amount of recovered protein ("Total IgA2") and its activity ("Active IgA2") were quantified by BCA assay and by HIV neutralization assay, respectively, as described in the text. 

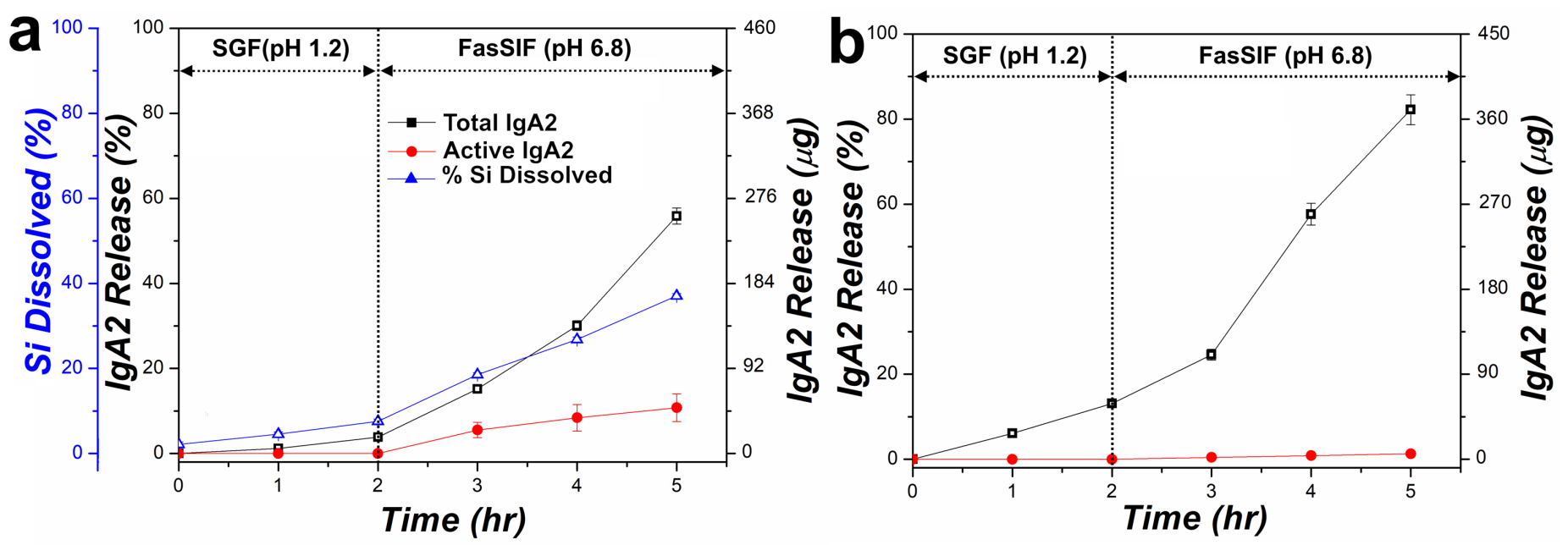

Figure S4. In-vitro temporal release curves comparing IgA2 released from Eudragit ${ }^{\circledR}$ L30 D-55-coated pSi formulation (a) and from pure Eudragit ${ }^{\circledR}$ L30 D-55 control (b). The test materials were placed in SGF for $2 \mathrm{~h}$ and then into fasting state simulated intestinal fluid (FasSIF) for an additional $3 \mathrm{~h}$. Total and active IgA2 released, and \% Si dissolved are presented. Total protein measured by BCA assay, total active IgA2 antibody measured by ELISA, and \% Si present in solution measured by molybdenum blue assay. 
R6G Release from Uncoated Capsule
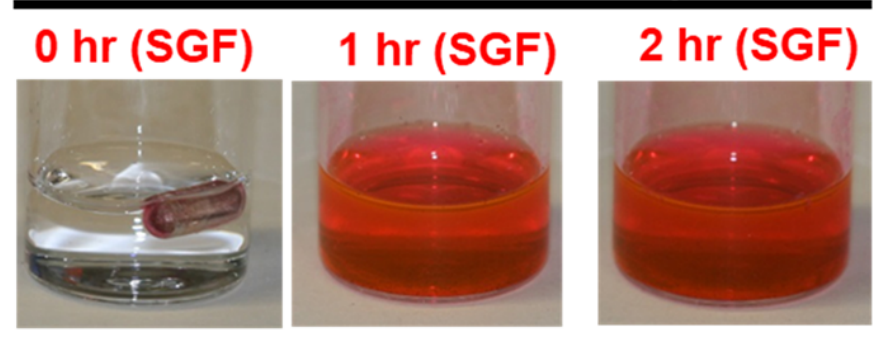

R6G Release from Eudragit ${ }^{\circledR}$ L100-coated Capsule
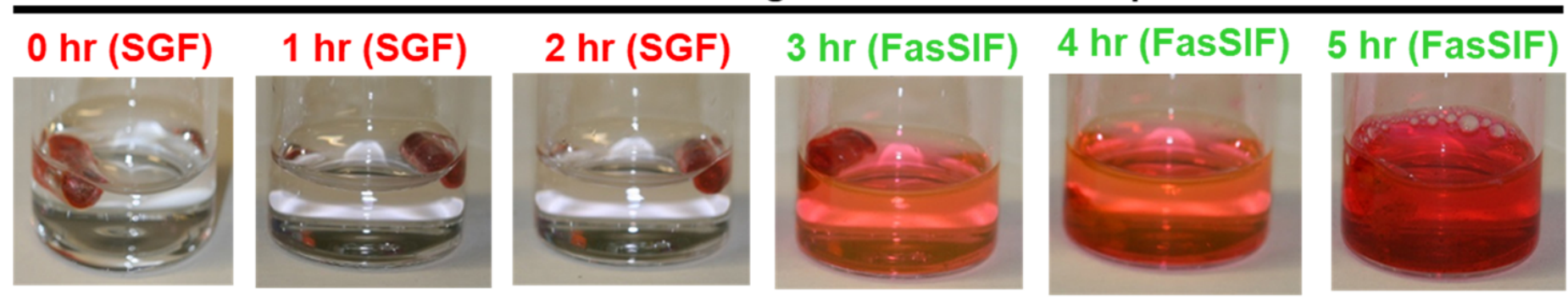

\section{R6G Release from Eudragit ${ }^{\circledR}$ S100-coated Capsule}
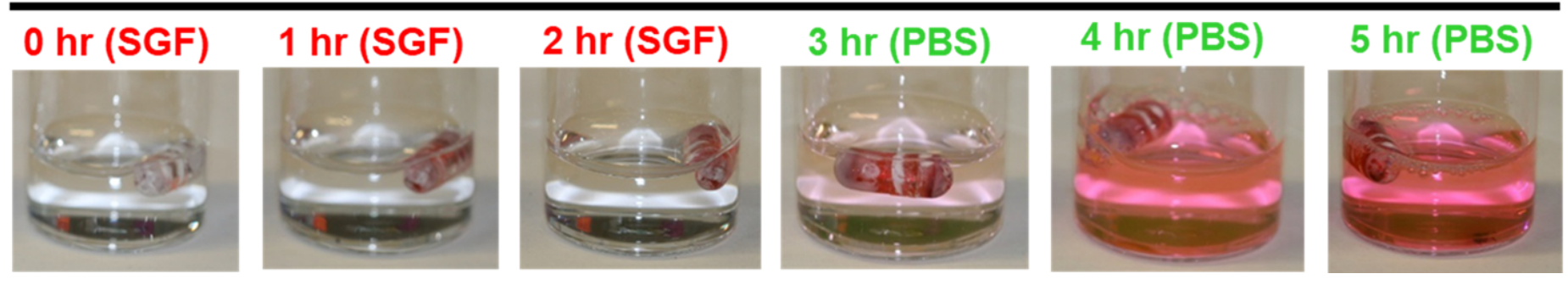

Figure S5. Photographs illustrating optimization coating of Eudragit ${ }^{\circledR}$ enteric polymer on gelatin capsules. The indicator dye rhodamine 6G was loaded inside gelatin capsules and these were then either coated with Eudragit ${ }^{\circledR}$ S100 or left uncoated and placed in the indicated solutions for the indicated periods of time. Top row: uncoated gelatin capsules placed in simulated gastric fluid (SGF). Middle row: Eudragit ${ }^{\circledR}$ L100-coated capsules placed in SGF for $2 \mathrm{~h}$ and then into fasting state simulated intestinal fluid (FasSIF) for an additional $3 \mathrm{~h}$. Bottom row: Eudragit ${ }^{\circledR}$ L100-coated capsules placed in SGF for $2 \mathrm{~h}$ and then into phosphate buffered saline (PBS) solution for an additional $3 \mathrm{~h}$. 


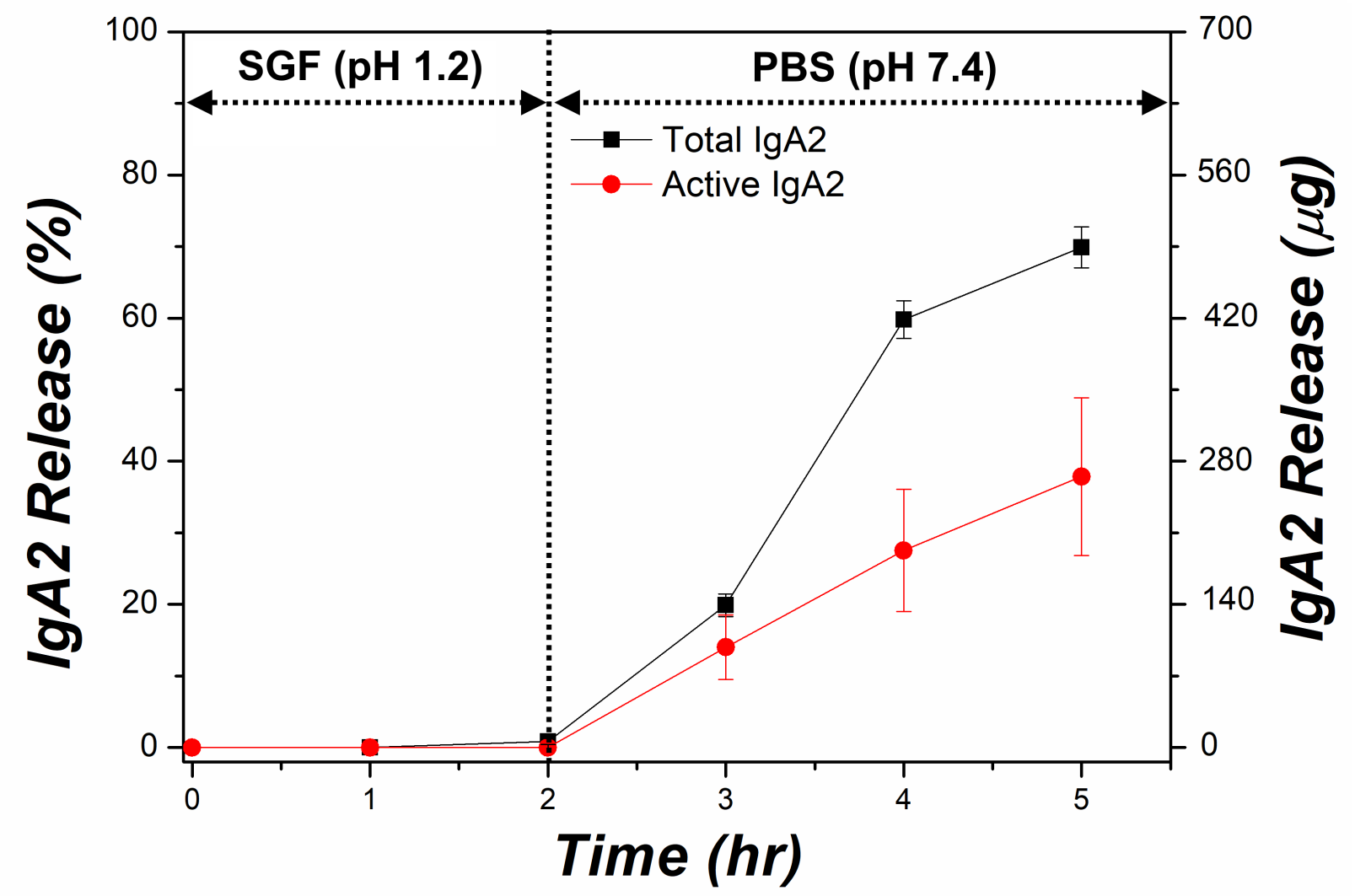

Figure S6. IgA2 released from Eudragit ${ }^{\circledR}$ L100 coated gelatin capsule into SGF and then into PBS. Percent of total and micrograms of IgA2 released from size 4 gelatin capsule packed with IgA2-loaded pSi particles. The plot shows total IgA2 and active IgA2 released from the capsule over a period of $5 \mathrm{~h}$; the first $2 \mathrm{~h}$ in SGF and remaining $3 \mathrm{~h}$ in PBS. $70 \%$ of the total loaded IgA2 was released during the $3 \mathrm{~h}$ period in PBS and $55 \%$ of the released IgA2 retained its activity. Total protein measured by BCA assay, total active IgA2 antibody measured by ELISA, and \% Si present in solution measured by molybdenum blue assay. 
Table S1. Oral protein delivery systems reported in the literature, comparing mass loading of drug, loading efficiency, activity of drug upon release, and percentage released in a $3 \mathrm{~h}$ time period in SIF or PBS.

\begin{tabular}{|c|c|c|c|c|c|c|}
\hline Protein & $\begin{array}{l}\text { Carrier } \\
\text { type }\end{array}$ & $\begin{array}{l}\text { Mass } \\
\text { loading (\%) }\end{array}$ & $\begin{array}{l}\text { Loading } \\
\text { efficiency (\%) }\end{array}$ & $\%$ activity & $\begin{array}{l}\% \text { Release in } 3 h \\
\text { in SIF or PBS }\end{array}$ & Ref \\
\hline $\operatorname{IgA} 2$ & $\begin{array}{l}\text { Eudragit }{ }^{\circledR} \text { - } \\
\text { coated pSi }\end{array}$ & $30-41$ & $55-60$ & $21-54$ & $55-75$ & This work \\
\hline Insulin & Liposome & $0.05-0.07^{*}$ & $45-66$ & n. g. & $5-30$ & 1 \\
\hline Insulin & Liposome & $5.0-13.0$ & $5-40$ & n. g. & n. g. & 2 \\
\hline Insulin & Liposome & $1.5^{*}$ & $40-45$ & $5.5^{* *}$ & n. g. & 3 \\
\hline Insulin & Liposome & n. g. & $25-67$ & $5-7^{* *}$ & $60-80$ & 4 \\
\hline Insulin & Liposome & 19.0 & $>95$ & n. g. & $15-50$ & 5 \\
\hline Insulin & Liposome & 3.2 & 76 & $13^{* *}$ & 100 & 6 \\
\hline Insulin & Liposome & $1.5-2.0$ & 85 & n. g. & n. g. & 7 \\
\hline $\begin{array}{l}\text { Salmon } \\
\text { calcitonin }\end{array}$ & Liposome & $1.9-2.2$ & 59 & $13^{* *}$ & $50-60$ & 8 \\
\hline $\begin{array}{l}\text { Salmon } \\
\text { calcitonin }\end{array}$ & $\begin{array}{l}\text { Chitosan- } \\
\text { Liposome }\end{array}$ & n. g. & $30-90$ & n. g. & $25-30$ & 9 \\
\hline Lysozyme & Liposome & $1.5-3.5$ & $22-50$ & n. g. & $10-95$ & 10 \\
\hline Ovalbumin & PEG-PLGA & 7.7-12.5 & $39-63$ & $37-74 * *$ & 12 & 11 \\
\hline $\begin{array}{l}\text { Salmon } \\
\text { calcitonin }\end{array}$ & PLGA NPS & $0.6-2.7$ & $11-95$ & $3 * *$ & n. g. & 12 \\
\hline Insulin & $\begin{array}{l}\text { PEG-Acrylic } \\
\text { copolymer }\end{array}$ & 7 & n. g. & n. g. & 100 & 13 \\
\hline Insulin & PLGA & n. g. & $85-95$ & $7^{* *}$ & $40-60$ & 14 \\
\hline Insulin & PLGA & $2.5-3.5$ & 65 & 6 & $60-70$ & 15 \\
\hline $\lg G$ & Silica & 39.3 & n. g. & n. g. & n. g. & 16 \\
\hline Insulin & Chitosan-pSi & 23.8 & n. g. & n. g. & n. g. & 17 \\
\hline Insulin & Thiolated-pSi & 20 & 59 & $4-6$ & 40 & 18 \\
\hline Ovalbumin & $\begin{array}{l}\text { Functionalized } \\
\text { Silica }\end{array}$ & $19-64$ & $60-70$ & n. g. & $\begin{array}{l}15-30 \\
20-40^{\#}\end{array}$ & 19 \\
\hline Insulin & $\begin{array}{l}\text { Polymer-Cp1- } \\
11 \text { peptide } \\
\text { composite }\end{array}$ & $24-28$ & $85-90$ & 60 & $30-35$ & 20 \\
\hline
\end{tabular}

Note: SIF is Simulated Gastric fluid and PBS is Phosphate buffer saline

* Calculated based on initial mass provided in the article, ** Bioavailability, 'n. g.' is "not given", and \# \% payload released in SIF 


\section{REFERENCES}

1. Battaglia, L.; Trotta, M.; Gallarate, M.; Carlotti, M. E.; Zara, G. P.; Bargoni, A., Solid lipid nanoparticles formed by solvent-in-water emulsion-diffusion technique: development and influence on insulin stability. J. Microencapsul. 2007, 24, 672-684.

2. Gallarate, M.; Trotta, M.; Battaglia, L.; Chirio, D., Preparation of solid lipid nanoparticles from W/O/W emulsions: preliminary studies on insulin encapsulation. J. Microencapsul. 2009, 26, 394-402.

3. Sarmento, B.; Martins, S.; Ferreira, D.; Souto, E. B., Oral insulin delivery by means of solid lipid nanoparticles. Int. J. Nanomed. 2007, 2, 743.

4. Zhang, N.; Ping, Q.; Huang, G.; Xu, W.; Cheng, Y.; Han, X., Lectin-modified solid lipid nanoparticles as carriers for oral administration of insulin. Int. J. Pharm. 2006, 327, 153-159.

5. Liu, J.; Gong, T.; Wang, C.; Zhong, Z.; Zhang, Z., Solid lipid nanoparticles loaded with insulin by sodium cholatephosphatidylcholine-based mixed micelles: preparation and characterization. Int. J. Pharm. 2007, 340, $153-162$.

6. Zhang, Z.-H.; Zhang, Y.-L.; Zhou, J.-P.; Lv, H.-X., Solid lipid nanoparticles modified with stearic acid-octaarginine for oral administration of insulin. Int. J. Nanomed. 2012, 7, 3333.

7. Wang, S.; Xie, S.; Zhu, L.; Wang, F.; Zhou, W., Effects of poly (lactic-co-glycolic acid) as a co-emulsifier on the preparation and hypoglycaemic activity of insulin-loaded solid lipid nanoparticles. IET Nanobiotechnol. 2009, 3, 103-108.

8. Fan, T.; Chen, C.; Guo, H.; Xu, J.; Zhang, J.; Zhu, X.; Yang, Y.; Zhou, Z.; Li, L.; Huang, Y., Design and evaluation of solid lipid nanoparticles modified with peptide ligand for oral delivery of protein drugs. European J. Pharm. Biopharm. 2014, 88, 518-528.

9. Garcia-Fuentes, M.; Torres, D.; Alonso, M. J., New surface-modified lipid nanoparticles as delivery vehicles for salmon calcitonin. Int. J. Pharm. 2005, 296, 122-132.

10. Christophersen, P.; Zhang, L.; Yang, M.; Nielsen, H. M.; Müllertz, A.; Mu, H., Solid lipid particles for oral delivery of peptide and protein drugs I-elucidating the release mechanism of lysozyme during lipolysis. Eur. J. Pharm. Biopharm. 2013, 85, 473-480.

11. Rietscher, R.; Czaplewska, J. A.; Majdanski, T. C.; Gottschaldt, M.; Schubert, U. S.; Schneider, M.; Lehr, C.-M., Impact of PEG and PEG-b-PAGE modified PLGA on nanoparticle formation, protein loading and release. Int. J. Pharm. 2016, 500, 187-195.

12. Sang Yoo, H.; Gwan Park, T., Biodegradable nanoparticles containing protein-fatty acid complexes for oral delivery of salmon calcitonin. J. Pharm. Sci. 2004, 93, 488-495.

13. Cui, F.; Shi, K.; Zhang, L.; Tao, A.; Kawashima, Y., Biodegradable nanoparticles loaded with insulin-phospholipid complex for oral delivery: preparation, in vitro characterization and in vivo evaluation. J. Control. Release 2006, 114, 242-250.

14. Foss, A. C.; Goto, T.; Morishita, M.; Peppas, N. A., Development of acrylic-based copolymers for oral insulin delivery. Eur. J. Pharm. Biopharm. 2004, 57, 163-169.

15. Cui, F. d.; Tao, A. j.; Cun, D. m.; Zhang, L. q.; Shi, K., Preparation of insulin loaded PLGA-Hp55 nanoparticles for oral delivery. J. Pharm. Sci. 2007, 96, 421-427.

16. Meka, A. K.; Abbaraju, P. L.; Song, H.; Xu, C.; Zhang, J.; Zhang, H.; Yu, M.; Yu, C., A Vesicle Supra-Assembly Approach to Synthesize Amine-Functionalized Hollow Dendritic Mesoporous Silica Nanospheres for Protein Delivery. Small 2016, 12, 5169-5177.

17. Shrestha, N.; Shahbazi, M.-A.; Araújo, F.; Zhang, H.; Mäkilä, E. M.; Kauppila, J.; Sarmento, B.; Salonen, J. J.; Hirvonen, J. T.; Santos, H. A., Chitosan-modified porous silicon microparticles for enhanced permeability of insulin across intestinal cell monolayers. Biomater. 2014, 35, 7172-7179.

18. Shrestha, N.; Araújo, F.; Shahbazi, M. A.; Mäkilä, E.; Gomes, M. J.; Herranz-Blanco, B.; Lindgren, R.; Granroth, S.; Kukk, E.; Salonen, J., Thiolation and Cell-Penetrating Peptide Surface Functionalization of Porous Silicon Nanoparticles for Oral Delivery of Insulin. Adv. Funct. Mater. 2016, 26, 3405-3416.

19. Amin, M. K.; Boateng, J. S., Surface Modification of Mobile Composition of Matter (MCM)-41 Type Silica Nanoparticles for Potential Oral Mucosa Vaccine Delivery. J. Pharm. Sci. 2020, 109, 2271-2283.

20. Chen, X.; Ren, Y.; Feng, Y.; Xu, X.; Tan, H.; Li, J., Cp1-11 peptide/insulin complex loaded pH-responsive nanoparticles with enhanced oral bioactivity. Int. J. Pharm. 2019, 562, 23-30. 